\title{
Approaching Cave Level Identification with GIS: A Case Study of Carter Caves
}

\author{
Brianne S. Jacoby, ${ }^{1}$ Eric W. Peterson, ${ }^{1}$ John C. Kostelnick, ${ }^{1}$ and Toby Dogwiler ${ }^{2}$ \\ ${ }^{1}$ Department of Geology Geography, Illinois State University, Campus Box 4400, Normal, IL 61790-4400, USA \\ ${ }^{2}$ Southeastern Minnesota Water Resource Center, Department of Geosciences, Winona, MN 55987, USA \\ Correspondence should be addressed to Eric W. Peterson; ewpeter@ilstu.edu
}

Received 3 June 2013; Accepted 28 July 2013

Academic Editors: J. P. Suc and X.-M. Yang

Copyright (c) 2013 Brianne S. Jacoby et al. This is an open access article distributed under the Creative Commons Attribution License, which permits unrestricted use, distribution, and reproduction in any medium, provided the original work is properly cited.

\begin{abstract}
Cave passages that are found at similar elevations are grouped together and called levels. The current understanding is that passages within a level are speleogenetically linked to a common static baselevel or stratigraphic control. Cave levels have provided an interpretive framework for deciphering cave development, landscape evolution, and climatic changes. Cosmogenic dating has been successfully used to interpret levels in Mammoth Cave and the Cumberland Plateau; however, this technique is expensive and there are limited funding resources available. Geographic information systems may be used as preliminary procedures to identify cave levels and constrain the timing of level development. A GIS method is applied to the Carter Cave system in northeastern Kentucky. Cave entrance elevations along stream valleys were found by extracting elevation values from a $10 \times 10 \mathrm{~m}$ digital elevation model. Using a histogram generated from the frequency of cave elevations and a natural breaks classifier, four cave levels were identified in the Carter Cave system. This work improves the understanding of the Carter Cave system evolution and contributes toa methodology that can be used to ascertain an erosion history of karst systems.
\end{abstract}

\section{Introduction}

In fluviokarst, dissolution creates a system vertically and horizontally connecting surface and subsurface flow paths. Passage development is dependent on the elevation of base flow, stratigraphy, the diversion of water in the unsaturated zone to lower levels, discharge variations, and variations in chemistry [1]. Long periods of static base level with active dissolution allow for large passages to develop in discrete levels, graded to the regional hydrologic network. When river incision occurs as a result of regional base level lowering, groundwater flow is diverted to lower elevations [1-3]. Subsequently, dissolution and passage enlargement is limited or stopped in the abandoned upper levels as karst development becomes focused at the new base level. Alternating sequences of base level incision and aggradation results in a complex overprinting of level development with transitional passage morphologies and deposition or removal of broadly distributed sediment packages [4]. Deciphering the history of speleogenesis in such systems, including the delineation of cave levels, provides insight into the history of past base level changes and the associated glacio-eustatic or tectonic processes.

Passages that are created by static base level and correlate with other passages at similar elevations are grouped together and considered a layer or level. These cave levels are understood to be significant landforms left in the rock record that can help to decipher the timing of cave system development (e.g., $[4,5])$. As described above, multilevel caves form by episodic lowering of the local base level in response to regional discharge changes. Deciphering where the flow has changed from predominantly horizontal flow to vertical flow is considered to define the cave level boundary [1].

Approximately 5 million ha (55\%) of Kentucky is underlain by karstic limestone [6]. One high-density karst area is Carter County in northeastern Kentucky where a quarter of the area is associated with karst landform development [7]. The Carter Cave system is a highly developed karst system with multiple caves and passageways throughout the limestone of the area (Figure 1). Located roughly $290 \mathrm{~km}$ eastnortheast of the Mammoth Cave system, the Carter Caves 


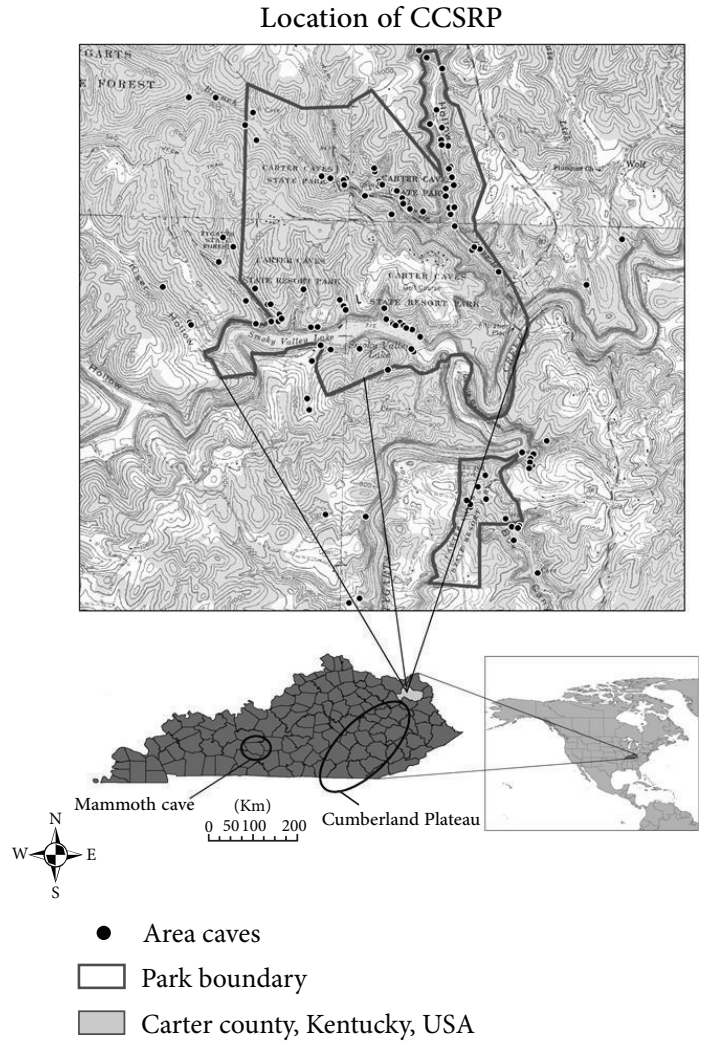

FIgURE 1: Location of Carter Caves State Resort Park (CCSRP).

area is centered primarily within Carter Cave State Resort Park (CCSRP).

CCSRP consists of approximately $106 \mathrm{~km}^{2}$ of deeply incised valleys, characteristic of the Cumberland Plateau. Within CCSRP, Cave Branch and Horn Hollow Creek are the main surface tributaries. Flow in Cave Branch is perennial. Horn Hollow Creek runs through Horn Hollow Valley, which is intensely karstified and primarily drained by subsurface flow [8]. While a surface stream channel is present within the valley, upstream Bowel Spring the surface flow is ephemeral and only observed during high-precipitation events when subsurface flow paths become inundated and overflowing. Between Bowel Spring and Horn Hollow Cave, Horn Hollow Creek flows along the surface. Upon exiting Horn Hollow Cave, flow is diverted through the subsurface. The waters exit the subsurface at $\mathrm{H}_{2} \mathrm{O}$ Cave and flow into Cave Branch. Waters of Cave Branch eventually flow into Tygarts Creek, the local control of base level, near the southern boundary of the park. After receiving the waters from Cave Branch, Tygarts Creek flows north into the Ohio River.

CCSRP has over 130 documented caves and over $18 \mathrm{~km}$ of mapped passageways. There are both phreatic and vadose caves within CCSRP [9]. In relatively flat-lying rocks, measured dips of rocks are $2^{\circ}$ at CCSRP [7], and phreatic caves form primarily along bedding planes. Vadose passages form along vertical structures, such as bedrock joints. As a result of the low regional dip and bedding plane control, the caves within CCSRP are horizontal [7]. Caves are present within the Mississippian-aged Newman Formation, and the St. Genevieve is the major cave forming unit.

Prior to the onset of the Pleistocene glaciations, landscape denudation and evolution were occurring at a relatively slow rate, and base level was much more static than it has been since the onset of glaciation [4]. This period of stability provided sufficient means to develop some of the very large upper-level trunk conduits found within Mammoth Cave [4], the Cumberland Plateau [5], and in CCSRP [7, 9].

Before glaciation, northeastern Kentucky was part of the headwaters branch of the Teays River, which flowed from North Carolina north through the CCSRP region and on toward West Central Ohio [10, 11]. Although the area lies south of the Pleistocene glacial maximum, north flowing rivers were frequently dammed and diverted by ice sheets $[4,12]$. During periods of stream impoundment, sediments accumulated in the valleys. A. S. Engel and S. A. Engel [7] proposed that the sediments in upper-level caves at CCSRP (e.g., Saltpetre Cave) are preserved remnants of these deposits. As the Ohio River drainage reorganized during the later portion of the Pleistocene, much of the southerly portion of the old Teays drainage in eastern Kentucky and West Virginia was captured [11-14]. When the glacially impounded valleys are drained or when the Ohio River is incised, base level changes occurred. Periods sustained and stable base level would result in karst development graded along or just below the water table [1]. Granger et al. [4] and Anthony and Granger [5] have demonstrated that these base level changes have been recorded in a consistent manner in both Mammoth Cave System and the caves of the Cumberland Plateau.

While published reports on the karst of CCSRP are limited, a number of researchers have investigated the area. Geographic locations of cave entrances were assembled in an unpublished database by the Wittenberg University Speleological Society. Dogwiler and Wicks [15] assessed the sediment entrainment dynamics and frequency within the Cave Branch and Horn Hollow karst systems. Woodside [16] surveyed and analyzed the surface features to determine if they formed as a result of surface processes or cave collapse and provided insight into the speleogenesis of Horn Hollow Valley and the connectivity of caves. Peterson et al. [9] proposed a preliminary delineation of four cave levels in CCSRP based on Geographic Information System (GIS) analysis using a $30 \mathrm{~m}$ digital elevation model (DEM). Jacoby et al. [17] presented an analysis of erosion susceptibility for the area that indicated the areas with high sensitivity to erosion do not correlate with areas with a high density of caves.

The goal of this study is to refine the model of cave level delineation proposed by Peterson et al. [9]. This work seeks to improve upon the methods of Peterson et al. [9] by using a $10 \mathrm{~m}$ DEM rather than a $30 \mathrm{~m}$ DEM. The smaller grid size provides better sampling and improves the elevation delineations $[18,19]$. Deng et al. [20] discuss the relationship between terrain analysis and scale across landscapes and conclude that resolution affects point-specific and topographic attributes. We hypothesize that by increasing the DEM resolution, more accurate and lower error cave level elevations and distance measurements between cave openings and streams will be 
found. We expect these results to better define the range of level elevations than the current research provides.

\section{Site Description}

A. S. Engel and S. A. Engel [7] and Ochsenbein [21] provide detailed descriptions of the stratigraphy and topography of CCSRP. Below we highlight important aspects. The bedrock formations within CCSRP are similar to those at Mammoth Cave although the unit thicknesses are thinner in the CCSRP area. The primary cave forming unit is the Mississippian-aged Newman Formation, which is comprised of, from oldest to youngest, the St. Louis Limestone, the St. Genevieve Limestone, and the Upper Member of the Newman Formation. The entire formation is approximately $60 \mathrm{~m}$ thick. Joints are prominent in the Upper Member of the Newman Formation and St. Genevieve limestones, providing recharge sites for aggressive waters that drive dissolution of the carbonate rock $[7,8]$. As a result of the low regional dip, $2^{\circ}$, the caves of the area are horizontal. Some caves are multileveled caves, with levels offset by at least $5 \mathrm{~m}[22,23]$. Detailed cave maps of selected caves have been published by Pfeffer et al. [23], Hobbs and Pender [22], and A. S. Engel and S. A. Engel [7]. The Pennsylvanian-aged Pennington Formation, a $100 \mathrm{~m}$ thick sandstone, overlies the Newman Formation, with the contact occurring uniformly at $273 \mathrm{~m}$. The Mississippianaged Borden Formation underlies the Newman Formation and can be found outside of the park and along the bed of Tygarts Creek. The Borden Formation is a shale and restricts the downcutting in the area.

\section{Methods}

GIS was used to find and visualize the location of levels within CCSRP. Data sets used in the software include cave entrance locations, DEM-derived elevations, and stream networks. Cave entrance latitude and longitude values were compiled from geospatial positioning system (GPS) measurements and a $1 / 3$ arc second (approximately $10 \mathrm{~m}$ ) DEM. The cave entrance data were provided by the Wittenberg University Speleological Society (Horton Hobbs, personal communication), and the DEM was obtained from the US Geological Surveys Seamless website (http://seamless.usgs.gov/). The DEM was used to elicit the elevations of cave openings and to determine the stream network in the region. Typical horizontal accuracy associated with these DEMs according to the National Standard for Spatial Data Accuracy is approximately $13.906 \mathrm{~m}$, and the vertical accuracy is approximately $0.363 \mathrm{~m}$ [24].

The DEM and cave opening datasets were used in the GIS to locate the cave level elevations by extracting elevation values from the DEM for each cave point. A histogram was created displaying the frequency of cave entrances and exits at each elevation. Levels were defined from a combination of natural breaks statistical classifier in the GIS (TwoStep Cluster analysis using PASW Statistics 18) and visual inspection of the histogram.
To determine the horizontal distance (Euclidean distance) between cave entrances and the adjacent surface stream path, a stream network was derived using the hydrology tools in the GIS. A vector stream network layer at a scale of $1: 24,000$ was available from the Kentucky Geological Society, but it did not provide enough detail for this study. When creating the stream network a threshold of accumulation, or total number of cells that flow into a given area, has to be determined. During field work, the locations from heads of streams were recorded with a GPS unit and later viewed in the GIS. Using the recorded locations, a threshold value of 70 cells was determined to most accurately represent the CCSRP stream network. Euclidean (straight-line) distance between cave entrances and streams was then calculated and output in the form of a raster grid with each cell at the location of a cave containing the distance in metre to the nearest stream segment.

\section{Results and Discussion}

In their investigation of the levels at CCSRP, Peterson et al. [9] conducted an error analysis comparing 43 field-measured elevations for karst features and surveyed benchmarks, derived from both a Kestrel electronic altimeter and a GPS unit, to elevations derived from a $30 \mathrm{~m}$ DEM. Elevations obtained from the $30 \mathrm{~m}$ DEM were slightly higher than those measured in the field, with a mean error of $-0.48 \mathrm{~m}$ and a $95 \%$ confidence interval (CI) of $1.25 \mathrm{~m}$. Based on the associated error, they concluded that DEMs provided an efficient way of obtaining elevation values for cave openings. Using the $10 \mathrm{~m}$ DEM, the accuracy of modeled elevations was improved, decreasing the mean error to $-0.28 \mathrm{~m}$ with a $95 \%$ CI of $1.03 \mathrm{~m}$. Statistically, there is no difference in the mean error obtained from using the $30 \mathrm{~m}$ DEM as compared to those obtained using the $10 \mathrm{~m}$ DEM $[t(84)=0.75, P=0.46]$. However, the $10 \mathrm{~m}$ DEM error is lower than the vertical error of $0.36 \mathrm{~m}$ for the $10 \mathrm{~m}$ DEM. The lower error associated with the $10 \mathrm{~m}$ DEM suggests that the use of the higher resolution DEM is an improvement over the $30 \mathrm{~m}$ DEM.

A source of error for both the Peterson et al. [9] and this work is the placement of caves at elevations that would indicate that the cave was hosted in sandstone. The contact between the Upper Member of the Newman Limestone and the overlying Pennington Formation was found at $274 \mathrm{~m}$. Comparing the contact elevation to that of cave elevations determined from the $10 \mathrm{~m}$ DEM indicated that six cave entrances were contained within the sandstone unit (Figure 2). Although the cave entrances are all within limestone, there were cases where sandstone was located directly above the entrances. The resolution of the $10 \mathrm{~m} \mathrm{DEM}$ makes it appear as if some caves were in sandstone. These caves were kept in the data, but we understood them to be associated with the uppermost cave level (see shaded area in Figure 2).

Collectively, the elevations of the cave openings are normally distributed (Shapiro-Wilk Test $(W(142)=0.98, P=$ 0.27 ) (Figure 2). A higher frequency of openings exists between the elevations of 228 and $270 \mathrm{~m}$, but there are no 


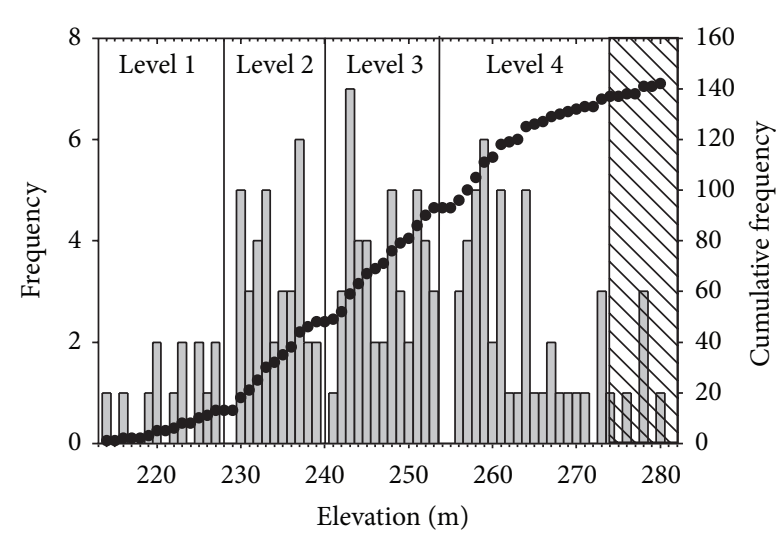

FIGURE 2: Histogram and cumulative frequency curve displaying cave elevation distribution in CCSRP. The shaded area represents caves with elevations above the limestone/sandstone contact $(>274 \mathrm{~m})$.

caves with openings at elevations of $240 \mathrm{~m}$ and $254 \mathrm{~m}$. Using those elevation gaps, groups of cave elevation openings were formed by natural breaks at the following elevations: $228 \mathrm{~m}$, $240 \mathrm{~m}$, and $254 \mathrm{~m}$. This classification was confirmed through a TwoStep Cluster Analysis that created four clusters centered at elevations of $222 \mathrm{~m}, 234 \mathrm{~m}, 247 \mathrm{~m}$, and $264 \mathrm{~m}$, which defined Levels 1, 2, 3, and 4, respectively.

The higher resolution $10 \mathrm{~m}$ DEM produced a different range of elevations for the levels and a higher distribution of caves in the upper levels than the $30 \mathrm{~m}$ DEM used by Peterson et al. [9]. While the elevation of levels found from the $10 \mathrm{~m}$ DEM was consistently lower than that delineated from a $30 \mathrm{~m}$ DEM, the reevaluation of the elevations classified more caves in the upper two levels and decreased the number in the lower two levels (Table 1). This appears to be a direct result of more accurate elevation assignments associated with the $10 \mathrm{~m}$ DEM (Table 1). The error analysis described earlier showed that the current study had a mean error that was $0.20 \mathrm{~m}$ less than that reported by Peterson et al. [9]. A higher DEM resolution and less error than the $30 \mathrm{~m}$ study explain why the cave level elevations found in the two studies are different. Although $30 \mathrm{~m}$ and $10 \mathrm{~m}$ DEMs are often generated from the same data source, the smaller cell size of the $10 \mathrm{~m} \mathrm{DEM}$ allows for more sampling and less generalizing of elevation values. Only a few studies compare the accuracy of $10 \mathrm{~m}$ and $30 \mathrm{~m} \mathrm{DEMs}$, and much of the research performed utilized slope classification and soil surveys. Hammer et al. [18] and Zhang et al. [19] both concluded that there is a measurable difference between DEMs with different spatial resolutions, and although minimal, the $10 \mathrm{~m} \mathrm{DEM}$ is an improvement over the $30 \mathrm{~m}$ DEM. Our results confirm their findings.

A relationship between cave elevation and frequency of openings is suggested from the data (Table 1 and Figure 3). More caves are located in the level(s) at the highest elevations and the number of caves decreases as elevation decreases. Level 4 contains the most caves followed in order by Level 3, Level 2, and Level 1. The greatest number of caves were found within the St. Genevieve; however, there are caves found in all limestone units. Caves of Level 4 reside within the Upper Member of the Newman Formation and within the upper portion of the St. Genevieve. Caves of Levels 3 and 2 are within the St. Genevieve. Caves of Level 1 formed within the St. Louis; however, the upper boundary of Level 1 may overlap within the St. Genevieve. Level development and formation host boundaries were estimated based on formation thicknesses [21], cave descriptions [7, 22, 23], and field observations.

The landscape of the region surrounding the CCSRP system includes deeply incised valleys that grade to gentle plateaus at higher elevations. Cave openings within the Carter Caves system are primarily located within the valley walls. Very few cave openings are found on the plateaus because the caves entrances occur where valley wall erosion has truncated passages. Additionally, the contact between the Upper Member of the Newman Formation and the overlying sandstone unit is very consistent at an elevation of $273 \mathrm{~m}$ as a consequence of the minimal regional dip of the units. The plateaus are capped by siliciclastic rocks (Figure 3 ), which inhibit cave development. Levels 1-3 are contained within the steep valley walls while Level 4 resides at the top of the valleys where the gradient becomes more gentle and the valley width widens.

At first glance, the Euclidean distances between the cave openings and the streams do not appear to have a relationship with level designation (Table 2 and Figure 4). The average and median Euclidean distances tend to increase with each successive cave level (Table 2). The exception is Level 1, where average distance is greater than those for Levels 2 and 3. However, Level 1 has the most cave openings $0 \mathrm{~m}$ from a stream. The average Euclidean distance is the greatest in Level 4 , supporting the hypothesis that the distance will be greatest for caves associated with the oldest level. The ranges for the distance between caves and streams for all levels begin at $0 \mathrm{~m}$. The maximum distance range for the top most levels is $139 \mathrm{~m}$ whereas the maximum distances for lower levels are within about $20 \mathrm{~m}$ of each other, ranging between 81 and $64 \mathrm{~m}$. A further look at these values indicates that they reflect the valley wall morphology and the hill-slope erosion processes. The lower levels contain steeper valleys and have evidence of cave collapse.

The relationship between streams and cave openings cannot be explained solely by surface processes. When there were events of rapid entrenchment, water was redirected through surface lows, rock fractures, and existing phreatic passageways [16]. These actions led to cave collapse in some areas. The valley geomorphology is the result of base level lowering, stratigraphy, and insufficient time for valley widening. The lack of wide, gradually sloping valleys can also be explained by a short-lived constant base level during level formation [25] and the high propensity for erosion within the valleys rather than the valley slopes [17]. With increasing elevation, there is more likelihood that erosional processes have stepped the valley wall back further from the active stream channel. The range of Euclidean distance values for the higher cave levels is the result of variation in valley crosssectional morphology from steep-sided and canyon-like to more gently sloping profiles. 
TABLE 1: Distributions of caves and cave elevation in relation to their corresponding level for the $30 \mathrm{~m}$ DEM and the $10 \mathrm{~m}$ DEM results.

\begin{tabular}{lcccccc}
\hline & \multicolumn{2}{c}{$30 \mathrm{~m}$ DEM [9] } & \multicolumn{3}{c}{$10 \mathrm{~m}$ DEM } \\
$\begin{array}{c}\text { Level elevation } \\
\text { range }(\mathrm{m})\end{array}$ & $\begin{array}{c}\text { Percentage of caves } \\
\text { in level (\%) }\end{array}$ & $\begin{array}{c}\text { Level elevation } \\
\text { range }(\mathrm{m})\end{array}$ & $\begin{array}{c}\text { Percentage of caves } \\
\text { in level (\%) }\end{array}$ & $\begin{array}{c}\text { Number of caves } \\
\text { Cave elevation } \\
\text { Average (m) }\end{array}$ & Median (m) \\
\hline Level 4 & $268-298$ & 16 & $255-274$ & 36 & 52 & 266 \\
Level 3 & $249-266$ & 31 & $240-253$ & 30 & 44 & 264 \\
Level 2 & $235-247$ & 30 & $228-240$ & 25 & 37 & 247 \\
Level 1 & $215-234$ & 23 & $214-228$ & 9 & 13 & 234 \\
\hline
\end{tabular}
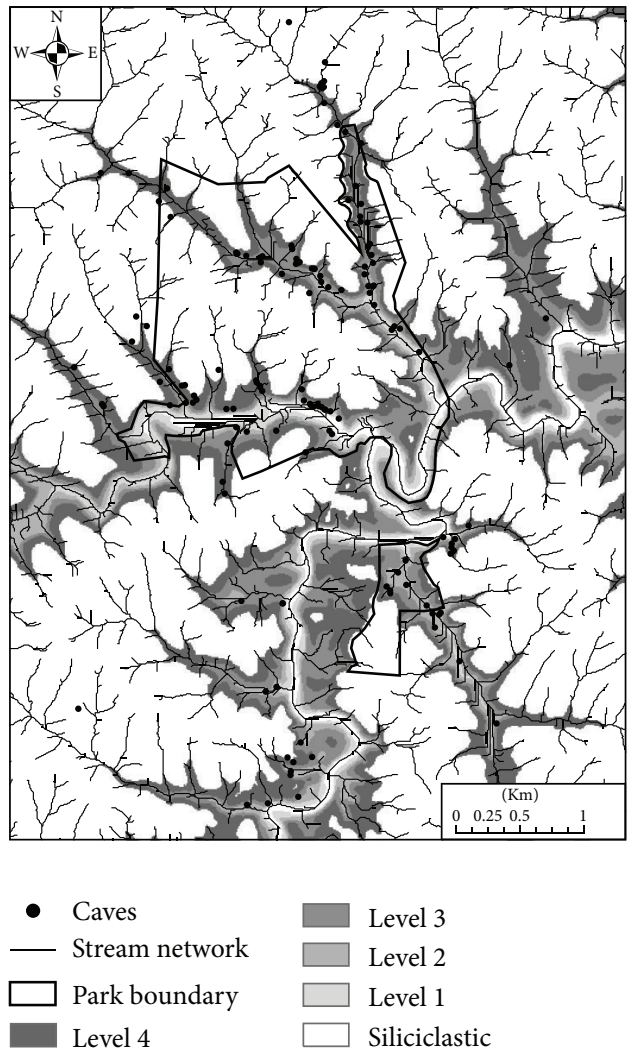

FIgURE 3: Spatial distribution of cave openings within the levels. Level 4 is the highest in elevation as well as the oldest in age. Siliclastic rocks include the Lee and Carter Caves Sandstone present above the limestones and the Borden Formation below the limestones.

TABLE 2: Distribution of distance between caves and streams in relation to their corresponding level. Level 4 is inferred to be the oldest levels, while Level 1 is inferred to be the youngest level.

\begin{tabular}{lcccc}
\hline & $\begin{array}{c}\text { Distance } \\
\text { from stream } \\
\text { range }(\mathrm{m})\end{array}$ & $\begin{array}{c}\text { Average } \\
\text { stream } \\
\text { distance }(\mathrm{m})\end{array}$ & $\begin{array}{c}\text { Stream } \\
\text { median }(\mathrm{m})\end{array}$ & $\begin{array}{c}\text { Standard } \\
\text { deviation }\end{array}$ \\
\hline Level 4 & $0-139$ & 36 & 29 & 31 \\
Level 3 & $0-78$ & 18 & 10 & 18 \\
Level 2 & $0-81$ & 17 & 14 & 17 \\
Level 1 & $0-64$ & 20 & 20 & 19 \\
\hline
\end{tabular}

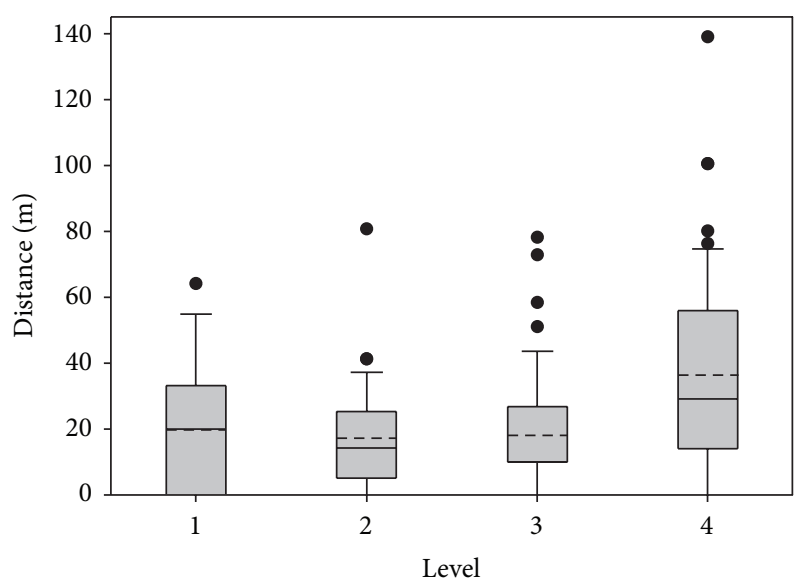

FIGURE 4: Relationship between levels and the distance between cave and streams. The ends of the boxes represent the 25th and 75th percentiles with the solid line at the median and the dashed line at the mean; the error bars depict the 10th and 90th percentiles and the points represent outliers. Mean increases with age level. Numerical values can be found in Table 2 .

\section{Conclusions}

Overall, the use of the GIS has proven successful in delineating the cave levels in a given area. The use of a $10 \mathrm{~m}$ DEM improved the accuracy of the results in comparison with the earlier study that employed $30 \mathrm{~m}$ DEMs. The number of cave levels is equivocal and can be reasonably interpreted as four. These findings correlate with past cave level studies performed in other karst systems in the region. Each of these studies reported a confident interpretation of four levels but suggested that a fifth level could be present.

Using the distance between cave openings and streams did not provide us with information about how many levels are present within CCSRP or where the levels are located. The distances provided insight into valley geomorphology and how the levels were exposed through river incision.

Future work could build on the interpretive framework presented here as a basis for determining the timing of cave level development through geochronologic methods. A limitation of the methodology employed in this study is the resolution of the available DEMs. As Lidar data becomes available, resolution will become less of a limitation. Cave levels separated by narrow bands of elevation that are smaller than 
the overall resolution of the terrain data will not be resolved. Likewise, this method requires caves to be daylighted at multiple elevations in order to use the DEM to identify cave elevations. However if passage elevations were known, then the use of a histogram would still be applicable to determine level elevations. Furthermore, without absolute dating techniques, this method does not elucidate where cave levels are overprinted on one another by successive base levels that return to a similar elevation. The latter issue can be largely resolved by careful observation of cave passage morphology and detailed analysis of the associated landscape morphology. This method was successful at CCSRP because the sediment units are relatively flat lying. Applying this method to an area with steeply dipping beds would be more difficult because geometry would have to be considered when interpreting the histogram. Levels would no longer be horizontal, and thus the natural break elevations would not be uniform throughout the site. In addition, this method also must be applied to karst areas with a thorough cave dataset in order to have enough samples for analysis. In the final analysis, DEM-based analysis of karst development has proven to be a cost-effective and straightforward means of delineating the vertical evolution of karst systems.

\section{Conflict of Interests}

The authors of the paper do not have a direct financial relation with any commercial entity mentioned in this paper.

\section{Acknowledgments}

The authors would like to thank Simone Runyon and Jonathan Love for their assistance in the field and the Wittenberg Speleological Society for providing their CCSRP database. The authors would like to thank three anonymous reviewers for their comments and suggestions that have improved this paper.

\section{References}

[1] A. N. Palmer, "Cave levels and their interpretation," NSS Bulletin, vol. 49, no. 2, pp. 50-66, 1987.

[2] A. N. Palmer, "Origin and morphology of limestone caves," Geological Society of America Bulletin, vol. 103, no. 1, pp. 1-21, 1991.

[3] W. B. White and E. L. White, "Channel hydraulics of freesurface streams in caves," Cave and Karst Science, vol. 12, no. 6, pp. 41-48, 1970.

[4] D. E. Granger, D. Fabel, and A. N. Palmer, "Pliocene-pleistocene incision of the Green River, Kentucky, determined from radioactive decay of cosmogenic ${ }^{26} \mathrm{Al}$ and ${ }^{10} \mathrm{Be}$ in Mammoth Cave sediments," Bulletin of the Geological Society of America, vol. 113, no. 7, pp. 825-836, 2001.

[5] D. M. Anthony and D. E. Granger, "A late Tertiary origin for multilevel caves along the western escarpment of the Cumberland Plateau, Tennessee and Kentucky, established by cosmogenic ${ }^{26} \mathrm{Al}$ and ${ }^{10} \mathrm{Be}$," Journal of Cave and Karst Studies, vol. 66, no. 2, pp. 46-55, 2004.

[6] L. J. Florea, R. L. Paylor, L. Simpson, and J. Gulley, "Karst GIS advances in Kentucky," Journal of Cave and Karst Studies, vol. 64, no. 1, pp. 58-62, 2002.
[7] A. S. Engel and S. A. Engel, "A field guide for the karst of Carter Caves State Resort Park and the surrounding area, Northeastern Kentucky," in Field Guide to Cave and Karst Lands of the United States, A. S. Engel and S. A. Engel, Eds., Karst Waters Institute Special Publication 15, pp. 154-171, Karst Waters Institute, Leesburg, Va, USA, 2009.

[8] P. McGrain, Geology of Carter and Cascade Caves Area, Special Publication 12, Series X, Kentucky Geological Survey, Lexington, Ky, USA, 1966.

[9] E. Peterson, T. Dogwiler, and L. Harlan, "Using GIS to identify cave levels and discern the speleogenesis of the Carter Caves karst area, Kentucky," in U.S. Geological Survey Karst Interest Group Proceedings, E. L. Kuniansky, Ed., Fayetteville, Ark, USA, April 2011, Volume Scientific Investigations Report 2011-5031: Reston, Va, USA, United States Geological Survey, pp. 94-103.

[10] R. E. Janssen, "The Teays River, ancient precursor of the East," The Scientific Monthly, vol. 77, no. 6, pp. 306-314, 1953.

[11] K. ver Steeg, “The Teays River," The Ohio Journal of Science, vol. 46, no. 6, pp. 297-307, 1946.

[12] E. C. Rhodehamel and C. W. Carlston, "Geologic history of the Teays Valley in West Virginia," Geological Society of America Bulletin, vol. 74, no. 3, pp. 251-274, 1963.

[13] W. M. Andrews Jr., Geologic Controls on Plio-Pleistocene Drainage Evolution of the Kentucky River in Central Kentucky, Series XII, Thesis 4, 11125, Kentucky Geological Survey, University of Kentucky, Lexington, Ky, USA, 2006.

[14] J. T. Teller, "Preglacial (Teays) and early glacial drainage in the Cincinnati Area, Ohio, Kentucky, and Indiana," Geological Society of America Bulletin, vol. 84, no. 11, pp. 3677-3688, 1973.

[15] T. Dogwiler and C. M. Wicks, "Sediment entrainment and transport in fluviokarst systems," Journal of Hydrology, vol. 295, no. 1-4, pp. 163-172, 2004.

[16] J. Woodside, A geomorphic investigation of a longitudinal profile, sediment mobility, and abrasion within a fluviokarst system [M.S. thesis], Illinois State University, Normal, Ill, USA, 2008.

[17] B. S. Jacoby, E. W. Peterson, and T. Dogwiler, "Identifying the stream erosion potential of cave levels in Carter Cave State Resort Park, Kentucky, USA," Journal of Geographic Information Systems, vol. 3, no. 4, pp. 323-333, 2011.

[18] R. D. Hammer, F. J. Young, N. C. Wollenhaupt, T. L. Barney, and T. W. Haithcoate, "Slope class maps from soil survey and digital elevation models," Soil Science Society of America Journal, vol. 59, no. 2, pp. 509-519, 1995.

[19] X. Zhang, N. A. Drake, J. Wainwright, and M. Mulligan, "Comparison of slope estimates from low resolution DEMS: scaling Issues and a fractal method for their solution," Earth Surface Processes and Landforms, vol. 24, pp. 763-779, 1999.

[20] Y. Deng, J. P. Wilson, and J. C. Gallant, “Terrain analysis," in The Handbook of Geographic Information Science, J. P. Wilson and A. S. Fotheringham, Eds., pp. 417-435, Blackwell, Oxford, UK, 2008.

[21] G. D. Ochsenbein, Origin of caves in Carter Caves State Park, Carter County, Kentucky [M.S. thesis], Bowling Green State University, Bowling Green, Ohio, USA, 1974.

[22] H. H. Hobbs III and M. M. Pender, "The Horn Hollow Cave system, Carter County, Kentucky," Pholeos, vol. 5, no. 2, pp. 1722, 1985.

[23] N. Pfeffer, T. J. Madigan, and H. H. Hobbs III, "Laurel Cave," Pholeos, vol. 2, no. 1, pp. 10-11, 1981.

[24] T. Blak, "DEM quality assessment," in Digital Elevation Model Technologies and Applications: The DEM Users Manual, D. F. 
Maune, Ed., pp. 425-448, American Society for Photogrammetry and Remote Sensing, Bethesda, Md, USA, 2007.

[25] J. T. Teller and R. P. Goldthwait, "The old Kentucky River: a major tributary to the Teays River," in Geology and Hydrogeology of the Teays-Mahomet Bedrock Valley Systems, W. N. Melhorn and J. P. Kempton, Eds., Volume Special Paper 258, pp. 29-42, The Geological Society of America, Boulder, Colo, USA, 1991. 

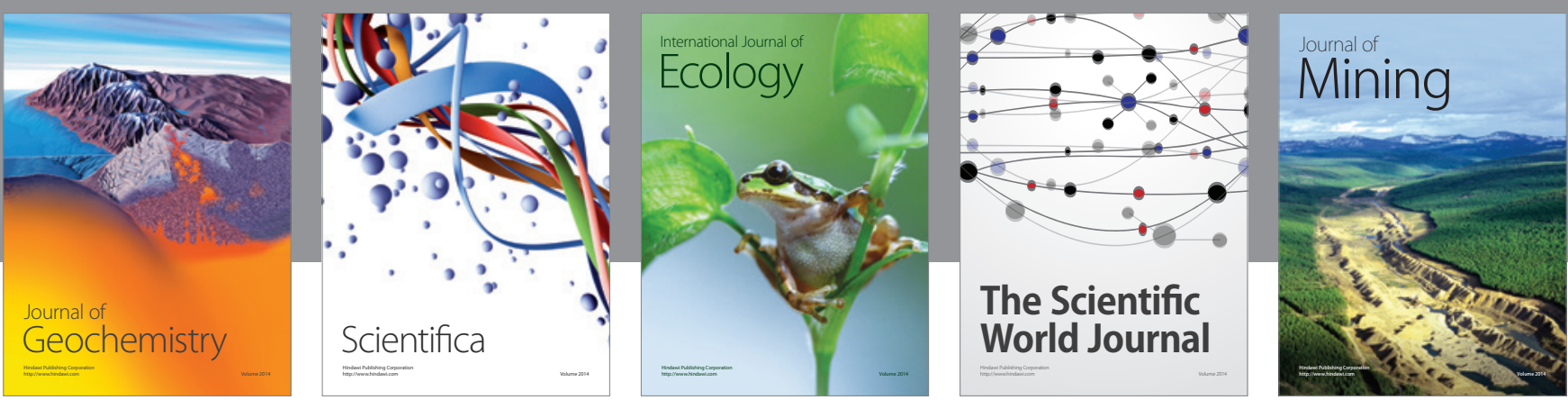

The Scientific World Journal
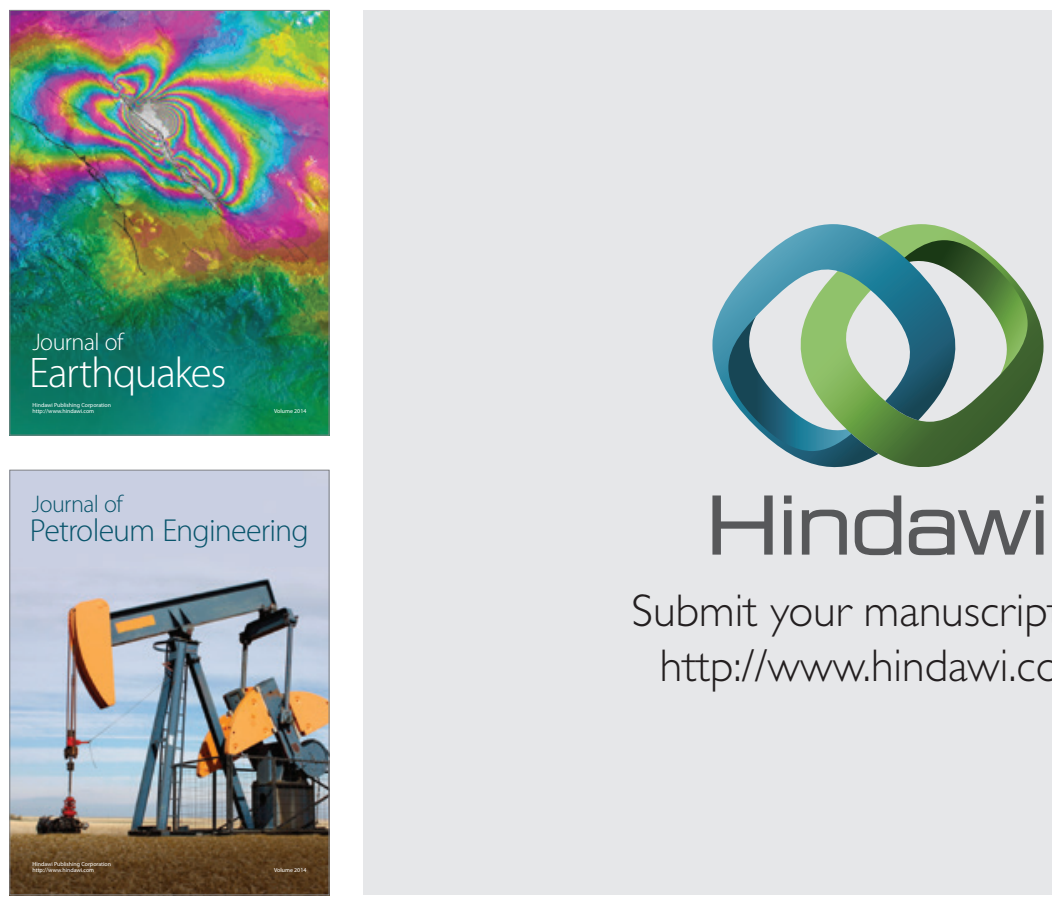

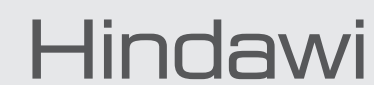

Submit your manuscripts at

http://www.hindawi.com
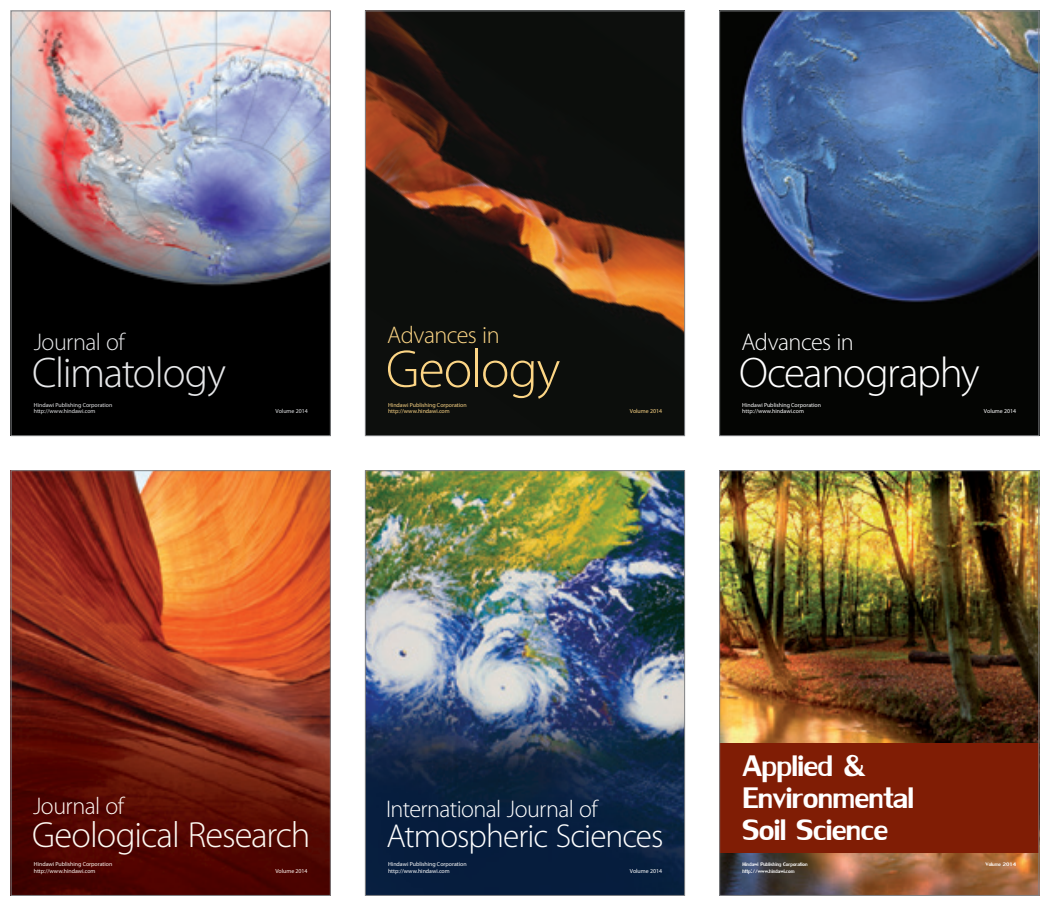
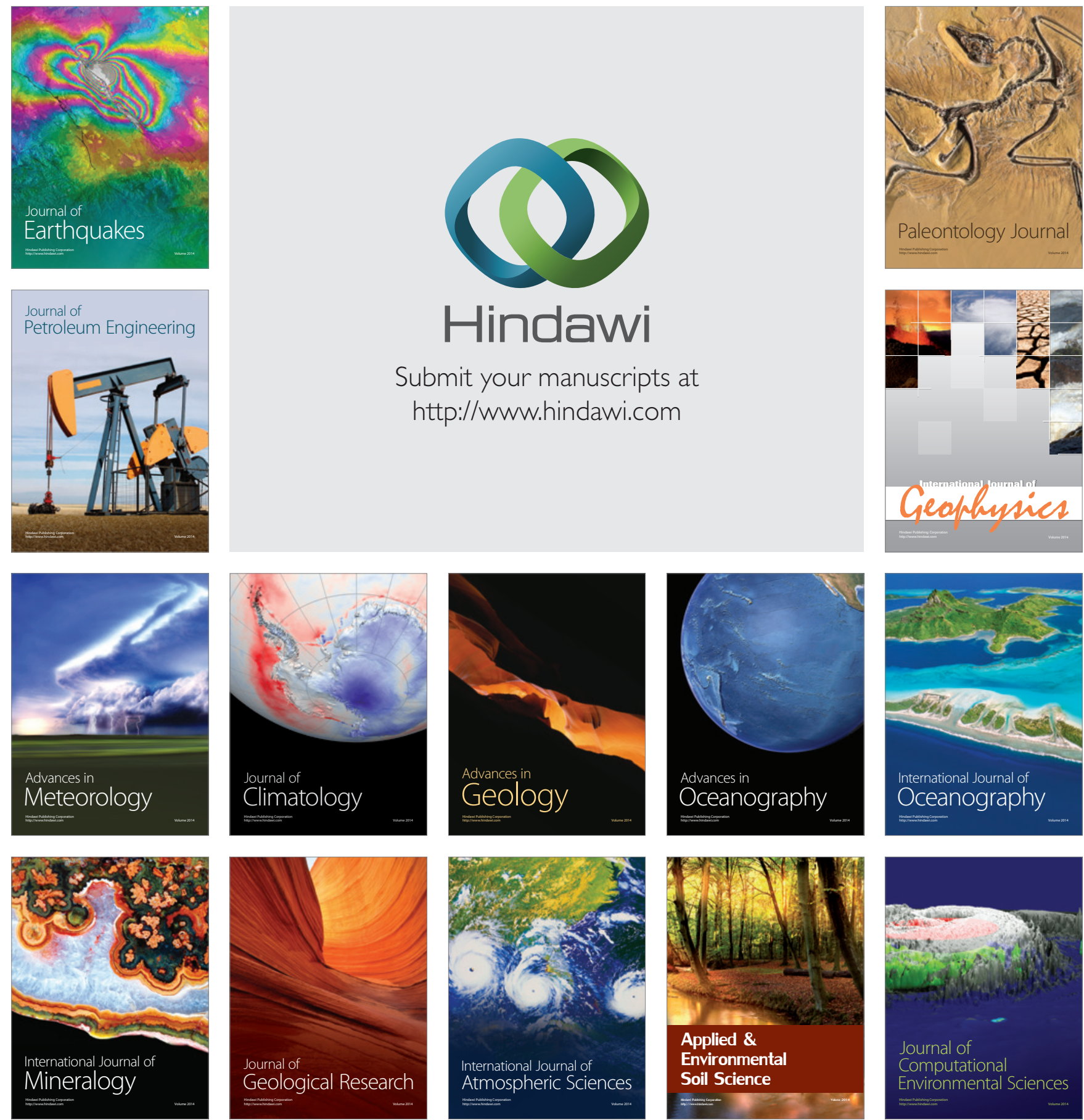